\title{
Milk composition of franciscana dolphin (Pontoporia blainvillei) from Rio Grande do Sul, southern Brazil
}

\author{
GLAUCO CAON $^{1,2}$, EDUARDO RESENDE SECCHI ${ }^{3,4}$, EDISON CAPP ${ }^{5}$ AND LUIZ CARLOS KUCHARSKI ${ }^{1}$ \\ ${ }^{1}$ Laboratório de Metabolismo e Endocrinologia Comparada, Departamento de Fisiologia, Universidade Federal do Rio Grande do \\ Sul, Rua Sarmento Leite 500, $2^{\circ}$ andar, Campus Centro, 90050-170, Porto Alegre, RS, Brazil, ${ }^{2}$ Grupo de Estudos de Mamíferos \\ Aquáticos do Rio Grande do Sul, R. Felipe Neri, 382 cj. 203, 90550-190, Bairro Auxiliadora, Porto Alegre, RS, Brazil, ${ }^{3}$ Laboratório de \\ Tartarugas e Mamíferos Marinhos, Departamento de Oceanografia, Fundação Universidade Federal do Rio Grande-FURG, Cx. \\ Postal 474, Rio Grande-RS, 96200-970, Brazil, “4aboratório de Mamíferos Marinhos, Museu Oceanográfico 'Prof. E.C. Rios'- \\ FURG, Cx. Postal 379, Rio Grande-RS, 96200-970, Brazil, ${ }^{5}$ Laboratório de Ginecologia e Obstetrícia, Hospital de Clínicas de Porto \\ Alegre, Departamento de Ginecologia e Obstetrícia-FAMED/UFRGS, Porto Alegre, RS, Brazil
}

\begin{abstract}
Milk is the only external energy source for mammals in their early stages of life. Its composition varies during lactation in baleen whales and pinnipeds, while only descriptive studies are available for odontocetes. The aim of this work was to identify the components of the milk of franciscana, Pontoporia blainvillei, from southern Brazil. Samples were manually collected from lactating females $(N=5)$ incidentally caught in the gill-net fishery. The amount of fat, protein, carbohydrate, mineral and trace metal content, and caloric value of the samples were estimated. Milk of the franciscana dolphin presented mean fat, protein and carbohydrate concentrations similar to those described for other coastal species. A significant increase in fat concentration was observed in winter months, with a higher energy density. Potassium was the mineral found in higher amounts. Zinc, mercury and copper were detected in low concentrations. Due to different habitat conditions along the species distribution, the presence of a highly seasonal reproductive period and inter-population genetic variability, studies on milk composition in other areas is recommended.
\end{abstract}

Keywords: milk composition; minerals, contaminants; franciscana; Pontoporia blainvillei; Brazil.

Submitted 13 March 2007; accepted 2 November 2007; first published online 17 March 2008

Milk composition has been well described for baleen whales, and variations of fat and protein concentration along the lactation period are reported (Oftedal, 1997). The amount of energy transferred to the offspring during lactation depends directly on the milk composition and on the total amount of milk ingested, and during this period they grow quickly and double in size (Oftedal, 1997). Studies about milk of odontoceti have been merely descriptive and there is no information available concerning variation in milk composition during lactation or lactating strategies (Oftedal, 1997). The difficult access to milk samples may explain this lack of information, since collection of these samples is only possible through accidental catches or strandings of lactating females (e.g. Peddemors et al., 1989; Rosas \& Lehti, 1996).

The franciscana, Pontoporia blainvillei, is a small cetacean species endemic to the south-western Atlantic Ocean. Its distribution, characteristically coastal, extends from Itaúnas $\left(18^{\circ} 25^{\prime} \mathrm{S} 030^{\circ} 42^{\prime} \mathrm{W}\right)$, Espírito Santo, Brazil, to Golfo Nuevo $\left(42^{\circ} 35^{\prime} \mathrm{S} 064^{\circ} 48^{\prime} \mathrm{W}\right)$, Patagonia, Argentina (Secchi et al., 2003). Very little is known about the physiology of this species, despite the high number of accidental captures

Corresponding author:

G. Caon

Email: glauco_caon@terra.com.br reported in all major fishing communities along its area of distribution, as this is probably the most threatened cetacean species in the south-western Atlantic (Secchi et al., 2002). In this work the milk composition of P. blainvillei was analysed through the identification of its nutritional content, seasonal variation, and mineral and metal content.

Milk samples were collected from five lactant P. blainvillei females accidentally caught in fishing nets from Rio Grande $\left(32^{\circ} 05^{\prime} \mathrm{S} 52^{\circ} 08^{\prime} \mathrm{W}\right.$ ) (samples CA05, CA010 and CA338) and Imbé fishing communities $\left(29^{\circ} 58^{\prime} \mathrm{S} 50^{\circ} 07^{\prime} \mathrm{W}\right.$ ) (samples GEMARSo547 and GEMARSo828), southern Brazil. Milk was manually collected about $24 \mathrm{~h}$ after death and stored at $-20^{\circ}$ C. Samples CA05 and CA010 were collected in the summer (January 1993 and February 1993) while samples GEMARSo547, GEMARSo828 and CA338 were collected in the winter (August 1998, August 2000 and June 2004, respectively).

Protein nitrogen was determined by the micro-Kjeldahl method (AOAC, 1990). Fat was determined by the Mojonnier ether extraction procedure (AOAC, 1990). Carbohydrate concentration was determined using the phenol sulphuric acid method (Chaplin, 1986). The caloric value of milk was estimated using fat and protein concentrations (AOAC, 1995). The cryoscopic index was obtained using a digital electronic cryoscope (MV 540, VAPRO ${ }^{\circledR}$ 5520; Wescor) (AOAC, 1975). 
Table 1. Milk composition of the franciscana, Pontoporia blainvillei, in Rio Grande do Sul, Brazil.

\begin{tabular}{|c|c|c|c|c|c|}
\hline \multirow[t]{2}{*}{ Composition } & \multicolumn{2}{|c|}{ Summer samples } & \multicolumn{3}{|c|}{ Winter samples } \\
\hline & CA05 & CAo10 & $\mathrm{CA}_{338}$ & GEMARSo547 & GEMARSo828 \\
\hline Fat $(\mathrm{g} / 100 \mathrm{~g})$ & 8.21 & 8.22 & 19.00 & 13.80 & 14.0 \\
\hline Protein $(\mathrm{g} / 100 \mathrm{~g})$ & 13.70 & 14.43 & 11.50 & 9.50 & 9.80 \\
\hline Carbohydrates (g/100 g) & n.a. & n.a. & 2.80 & 2.20 & 2.50 \\
\hline $\mathrm{pH}$ & 6.80 & 6.70 & n.a. & n.a. & n.a. \\
\hline Cryoscopic index & $\Delta-0.818^{\circ} \mathrm{C}$ & $\Delta-0.817^{\circ} \mathrm{C}$ & n.a. & n.a. & n.a. \\
\hline
\end{tabular}

n.a., not analysed.

It was possible to determine the composition of heavy metals and minerals in the sample CA338 only. A milk fraction was submitted to digestion with nitric acid (Standard Methods $\left.2 \mathrm{O}^{\mathrm{TH}}\right)$. The minerals potassium $(\mathrm{K})$, phosphorus $(\mathrm{P})$, sodium $(\mathrm{Na})$, calcium $(\mathrm{Ca})$, magnesium $(\mathrm{Mg})$ and iron (Fe) were quantified by absorption spectrophotometry. In samples CA05 and CA010, only the Ca concentration was determined by oxalate titration. All values were expressed as $\mathrm{mg} / \mathrm{l}$. Mercury $(\mathrm{Hg})$, lead $(\mathrm{Pb})$, cadmium $(\mathrm{Cd})$, zinc $(\mathrm{Zn})$ and copper $(\mathrm{Cu})$ were quantified by atomic absorption spectrophotometry and the values were expressed as $\mathrm{mg} / \mathrm{l}$, except for $\mathrm{Hg}(\mu \mathrm{g} / \mathrm{l})$.

To detect seasonal differences in milk composition, samples collected in summer and winter were compared. Fat and protein concentrations, as well as total length $(\mathrm{cm})$ and total weight $(\mathrm{kg})$ were compared using Student's $t$-test with Tukey procedures. Data were considered to be significant at $P \leq 0.05$.

Milk composition of $P$. blainvillei is shown in Table 1 . Fat concentrations found in summer $(15.60 \%)$ were statistically different to those observed in winter $(8.21 \%)$, with $P=$ 0.044 . Protein concentration was higher in summer (14.07\%) than in winter $(10.27 \%)$, with $P=0.021$. The lactant females had similar total lengths in summer and in winter (summer $=154.80 \pm 5.94 \mathrm{~cm}$; winter $=155.0 \pm 2.18 \mathrm{~cm} ; P=$ 0.958 ) and similar total weights (summer $=40.30 \pm 3.96 \mathrm{~cm}$; winter $=38.13 \pm 3.20 \mathrm{~cm} ; P=0.543)$.

In summer, the mean protein and fat concentrations in franciscana milk corresponded to $56.26 \mathrm{kcal} / 100 \mathrm{~g}$ and $73.85 \mathrm{kcal} / 100 \mathrm{~g}$, respectively, totalling $130.11 \mathrm{kcal} / 100 \mathrm{~g}$. The samples collected in winter corresponded to 181.47 $\mathrm{kcal} / 100 \mathrm{~g}$, a caloric value 1.9 folder higher than in summer, due to higher concentration of fat $(140.40 \mathrm{kcal} / 100 \mathrm{~g})$, while protein concentration corresponded to $41.07 \mathrm{kcal} / 100 \mathrm{~g}$. Carbohydrates, possibly lactose, showed a mean value of $2.5 \%$ in franciscana milk during winter. Values for summer were not available for comparison.

The concentrations of minerals and heavy metals analysed in sample $\mathrm{CA}_{33} 8$ were $\mathrm{K}=1521.0 \mathrm{mg} / \mathrm{l}, P=1454.0 \mathrm{mg} / \mathrm{l}$, $\mathrm{Na}=1054.0 \mathrm{mg} / \mathrm{l}, \mathrm{Mg}=89.20 \mathrm{mg} / \mathrm{l}$ and $\mathrm{Fe}=10.20 \mathrm{mg} / \mathrm{l}$. Calcium presented a concentration of $947.0 \mathrm{mg} / \mathrm{l}$, while samples CA05 and CA10 resulted in concentrations of $1460.0 \mathrm{mg} / \mathrm{l}$ and $1440.0 \mathrm{mg} / \mathrm{l}$, respectively. The metals found in sample $\mathrm{CA}_{33} 8$ were $\mathrm{Zn}=4.46 \mathrm{mg} / \mathrm{l}, \mathrm{Cu}=$ $0.63 \mathrm{mg} / \mathrm{l}$ and $\mathrm{Hg}=0.22 \mu \mathrm{g} / \mathrm{l}$. Lead $(\mathrm{Pb})$ and cadmium (Cd) concentrations were below the detection limits of analytical method ( $<0.05$ and $<0.002 \mathrm{mg} / \mathrm{l}$, respectively).

The milk of franciscana presented a low concentration of fat, similar to the Amazon River dolphin (Inia geoffrensis) (Rosas \& Lehti, 1996), bottlenose dolphin (Tursiops truncatus) and Indo-Pacific humpbacked dolphin (Souza plumbea) (Peddemors et al., 1989). Coastal species or populations of the same species generally have a lower fat concentration in milk compared to those of oceanic habits (Peddemors et al., 1989). We observed a variation of fat concentration in milk, being lower in summer $(8.21 \%)$ and higher in winter $(15.60 \%)$. The presence of proteins in franciscana milk presented a significant variation throughout lactation, higher in winter and lower in summer. However, the mean concentrations were similar to those of other cetacean species (Oftedal, 1997). There are no references concerning the variation of composition in other odontoceti. In other species, carbohydrates are present at values close to those found for franciscana (0.0-2.5\%) (Oftedal, 1997).

In spite of the low sample size, the data presesented in this study suggested that the milk of $P$. blainvillei presents a variation according to the lactation period. The differences between the beginning and the end of lactation in franciscanas may be under the influence of the sea temperature changes that are regulated by current regimens, with more energy provided to the calves through fat in colder months. Lactation in franciscanas occurs during nine months, and its ending coincides with the presence of the Falkland's current $\left(15-16^{\circ} \mathrm{C}\right)$ in Rio Grande do Sul (Danilewicz, 2003). This variation in composition may reflect the pattern of the milk in animals exclusive to the southern range of the species where its reproduction has a well-defined birth period from October to February in southern Brazil. This suggests at least the partial influence of temperature on the water during the time of birth and lactation for the species (Danilewicz, 2003). Variation in milk composition of mysticeti during the lactation period was observed, with fat increasing from $20 \%$ to $40 \%$ throughout the first six estimated months of lactation (mid-lactation) (Oftedal, 1997).

The mean concentration of $\mathrm{Cu}, \mathrm{Fe}, \mathrm{Zn}, \mathrm{Mg}$ and $\mathrm{Ca}$ concentrations were similar to other odontoceti (Oftedal, 1997). However, the concentrations of $\mathrm{Na}(1788.0 \mathrm{mg} / \mathrm{l})$ and $\mathrm{K}$ (7625.0 mg/l) found by Rosas \& Lehti (1996) for the Amazon River dolphin (I. geoffrensis) were higher than those found in this study. Zinc concentrations were higher in franciscana than in T. truncatus from the Mediterranean Sea (Frodello et al., 2002), and $\mathrm{Pb}, \mathrm{Cd}$ and $\mathrm{Cu}$ concentrations were lower. Franciscana showed $\mathrm{Hg}$ concentrations similar to T. truncatus (0.22 $\mu \mathrm{g} / \mathrm{l}$ vs $0.2 \mu \mathrm{g} / \mathrm{kg}$, respectively), but lower than that found in the Amazon River dolphin $(176.0 \mu \mathrm{g} / \mathrm{l})$ (Rosas \& Lehti, 1996). This high Hg concentration found in the Amazon River dolphin might be related to gold mining in the Amazon River (Rosas \& Lehti, 1996).

The variation in the composition of milk throughout lactation, as well as the evaluation of its nutritional components, 
are important information for the understanding of the energy input in the development and growth of P. blainvillei calves. Therefore, further studies are recommended with larger sample sizes in other regions.

\section{ACKNDWLEDGEMENTS}

The authors thank Dr Fernando C.W. Rosas (INPA), Daniel Danilewicz (GEMARS), Dr Adriano Brandelli (UFRGS) and the unknown referees for providing comments on drafts of this paper. This work received the financial support of CNPq (141315/2003-2), Fundação o Boticário de Proteção à Natureza (FBPN) and Fundo Nacional do Meio Ambiente (FNMA/Brazil).

\section{REFERENCES}

AOAC (1975) Official methods of analysis of the AOAC, 10th edn. Washington DC: Association of Official Analytical Chemists.

AOAC (1990) Official methods of analysis of the AOAC, 15th edn. Washington DC: Association of Official Analytical Chemists.

AOAC (1995) Official methods of analysis of the AOAC, 16 edn. Washington DC: Association of Official Analytical Chemists.

Chaplin M.F. (1986) Monosaccharides. In Chaplid M.F. and Kennedy J.F. (eds) Carbohydrate analysis. Oxford: IRL Press, pp. 1-36.

Danilewicz D. (2003) Reproduction of female franciscana (Pontoporia blainvillei) in Rio Grande do Sul, southern Brazil. Latin American Journal of Aquatic Mammals 2, 67-78.

Frodello J.P., Viale D. and Marchand B. (2002) Metal concentrations in the milk and tissues of a nursing Tursiops truncatus female. Marine Pollution Bulletin 44, 551-576.
Oftedal O.T. (1997) Lactation in whales and dolphins: evidence of divergence between baleen- and toothed-species. Journal of Mammary Gland Biology and Neoplasia 2, 205-230.

Peddemors V.M., Muelenaere H.J.H. and Devchand K. (1989) Comparative milk composition of the bottlenosed dolphin (Tursiops truncatus), humpback dolphin (Souza plumbea) and common dolphin (Delphinus delphis) from Southern African waters. Comparative Biochemistry and Physiology 94A, 639-641.

Rosas F.C.W. and Lehti K.K. (1996) Nutritional and mercury content of milk of the Amazon River Dolphin, Inia geoffrensis. Comparative Biochemistry and Physiology 115A, 117-119.

Secchi E.R., Danilewicz D. and Ott P.H. (2003) Applying the phylogeographic concept to identify franciscana dolphin stocks: implications to meet management objectives. Journal of Cetacean Research and Management 5, 61-68.

and

Secchi E.R., Ott P.H. and Danilewicz D. (2002) Report of the Fourth Workshop for the Coordinated Research and Conservation of the Franciscana Dolphin (Pontoporia blainvillei) in the Western South Atlantic. Latin American Journal of Aquatic Mammals (Special Issue) $1,11-20$.

\section{Correspondence should be addressed to:}

Glauco Caon

Laboratório de Metabolismo e Endocrinologia Comparada

Departamento de Fisiologia, Universidade Federal do Rio

Grande do Sul

Rua Sarmento Leite 500

$2^{\circ}$ andar Campus Centro 90050-170, Porto Alegre, RS

Brazil

email: glauco_caon@terra.com.br 